\title{
Part-Time Working Opportunities and the Impact on Students' Academic Achievement
}

\author{
Edwin Nuvianto Al Azis ${ }^{1}$, Gita Yusanti ${ }^{2}$ \\ ${ }^{1}$ Iain Kediri, Indonesia. Email: nuviantoe@ gmail.com \\ ${ }^{2}$ Iain Kediri, Indonesia, Email: gitayusanti14@gmail.com
}

\begin{tabular}{|c|c|}
\hline Article Info & Abstract \\
\hline $\begin{array}{l}\text { Article history: } \\
\text { Received: } 03 \text { June } 2021\end{array}$ & $\begin{array}{l}\text { Purpose: This research investigates the impact of being part-time-worker } \\
\text { students towards their academic achievement. }\end{array}$ \\
\hline Revised: 13 July 2021 & Methodology/Approach/Design: This research used qualitative descriptive \\
\hline Accepted: 15 July 2021 & $\begin{array}{l}\text { research method which is appropriate for the design of this research. The } \\
\text { data were collected from } 44 \text { higher students for the questionnaire and } 10\end{array}$ \\
\hline Keywords: & students for the interview at English Department, IAIN Kediri by \\
\hline $\begin{array}{l}\text { Part-Time Worker Students, } \\
\text { Academic Achievement, }\end{array}$ & $\begin{array}{l}\text { administering } 32 \text { questions for the questionnaire and } 14 \text { questions for the } \\
\text { interview. }\end{array}$ \\
\hline University Student. & $\begin{array}{l}\text { Results: The finding of this research is discovering that there are two main } \\
\text { motivations to be a part-time-worker student, financial factor and }\end{array}$ \\
\hline Paper Type : & $\begin{array}{l}\text { experience factor. However, the part-time-worker students are still able to } \\
\text { achieve good grade point average (GPA) or even they can achieve better }\end{array}$ \\
\hline Research Article & $\begin{array}{l}\text { academic achievement caused by the experience they got by being part-time- } \\
\text { worker student and it cannot be got from only being an ordinary academic }\end{array}$ \\
\hline Corresponding Author: & $\begin{array}{l}\text { student. Therefore, higher students can be a part-time worker students by } \\
\text { paying attention on time management which plays a pivotal role and finding }\end{array}$ \\
\hline Edwin Nuvianto Al Azis & $\begin{array}{l}\text { out a minimum duration for working but it can cover what their purposes } \\
\text { are. }\end{array}$ \\
\hline $\begin{array}{l}\text { Email: } \\
\text { nuviantoe@gmail.com }\end{array}$ & $\begin{array}{l}\text { Practical Implication: The findings of this study present various implications } \\
\text { for concerned authorities to address the emerging issues of university } \\
\text { students. Joining a part-time job has its merits and demerits. However, } \\
\text { further exploration of this phenomenon has to be implemented. } \\
\text { Originality/Value: The study examines a social issue that is continually, } \\
\text { aggravating. The results of the study offer an insider look into the students, } \\
\text { motifs and pressures exerted upon them to join part-time jobs. }\end{array}$ \\
\hline
\end{tabular}

1. Introduction

The term 'work-study' exists in some developed countries, such as: the United States, England, Singapore and many others. A study about young people in England reported that $27 \%$ students at adolescence age do both of studying and having a-time job (Rockika, 2017). However, many studies are only concerned with junior and senior high school students, and their involvement in employment became the subject of research and media. The work-study term is fundamentally associated with university students as well. Therefore, elucidating the data in the work-study of university students is the focus of this study. Moreover, one of the main factors affecting students' achievement is mainly about being part-time-worker students (Tessema et al., 2014). 
Dealing with the term of work-study in academic students is greatly appropriate with the current circumstance in Indonesian academic education but it does not fit with the situation in Indonesian junior and senior high schools because the occupational market of Indonesia does not support or provide for that chance. The phenomenon of being a part-time-worker student is increasing day by day. Due to financial reasons and experience requirements, university students join part-time jobs. There are two fortifications in noticing the term of work-study where one of them has a perception that it can improve the skill and ability of students in real job situation while the remaining have thought that it can disturb the time which must be used by the students for studying (Ali, 2017). Both of those opinions have their own reasons why they can state those. Some factors lead the students to succeed in conquering the term of work-study. However, the remaining students do not have those criteria which the bad impact will come to them.

One of the criteria is by managing the time properly between work and study. Prioritizing the school must never compromise with any kinds of reasons as a student. Poor time management becomes the main factor that can cause the stress mentality of students (Dipboye, 2014). An ordinary student who does not have a part-time job most of the time feels that they have a lack of time to work on the duties. These problems should engage some contributions from some viewpoints as well as the student itself. Particular time management is significant to avoid some bad impacts in this deal.

Moreover, in this pandemic era, the learning process is conducted via online class where all of the activities of learning are supposed to utilize the online platforms, such as zoom, google meet and many others. It definitely will make the students bored by having that full online class. They suppose that it is the same with having much or longer leisure time so that they decide to go working. The same case goes for academic students who mostly spend the learning process by dealing with the assignments. Therefore, it is greatly easy to manage the time between working and studying. The previous study elaborates that students who take more than 10 hours in a day for work will have a negative effect on their academic achievement (Oettinger, 2011). However, those studies are conducted before the pandemic. Therefore, the gap of this study is in the time of this study where it is taken in the pandemic era. Fundamentally, the students have much more leisure time.

Working while studying in the pandemic era can give another result paradoxically. All of the factors of the previous studies which are mostly triggered by how long they take a job in a day are particularly different in this pandemic era. Most of the previous results show that time is the most significant factor in the practice of studying while working (Beefy, 2010). Time management is greatly significant if students want to have such working while studying system. All of the negative impacts which will exist are fundamentally caused by failed time management. Time management itself deals with the way students divide and manage the time between working, studying, and taking a rest. In other words, the work-study students must be very disciplined and they must have and arrange the schedule to support and help easily in managing the time. 
Most students at IAIN Kediri who study in English Department decide to be a part-timeworker student so that they can fulfill their aims and goals by being a part-time-worker student. However, they are still supposed to prioritize the learning process. Therefore, this study is expected to comprehend deeply the impact of being part-time-worker students on their academic achievement. This study is also supposed to elaborate on how being part-timeworker students affect their academic achievement. This research may expand the way to minimize bad impacts in teaching part-time-worker students. Moreover, English teachers who especially teach students part-time-job students can consider the findings from a broader viewpoint. This can decrease the teaching problem when the teachers find difficulty in teaching work-study students. The problems can be discovered and the solution will be able to be found as well. This research can give a good way of explaining the impact of doing both pursuing an undergraduate degree and working at the same time and time management. Therefore, the weakness of doing that can be minimized to obtain better academic achievement. The work-study students must give much more effort in paying attention to time management to get success both in studying and working.

There are some studies which have a similar topic about being part-time-worker students, or it is most of the times called work-study. The first previous study is entitled "does part-time job affect college students' satisfaction and academic performance (GPA)? A case of a midsized public university" conducted by Mussie T. Tessema et al., in 2014. The study grouped between worked students and non-worked students. The data were collected from institutional planning, assessment and research where 5223 students became the respondents. The study has the result that the work-students have lower GPA than non-worked students, however, the worked students who have 0-10 hours per day had higher GPA. Therefore, the time of the work becomes the main factor. The second previous study is entitled "impact of part-time work on the academic performance of international students", the data are collected from different universities in Auckland Region. The result of this study shows that both positive and negative impacts exist in work study phenomenon. That is caused by a factor, such as time management. The third previous study is entitled "The impact of part-time work on educational outcomes" with the failed purpose in having the studying time. Moreover, it leads to two problems, such as day off and drop out. It has a big factor, time management. The failed time management leads to a serious problem, such as a day off and drop out as well as it will give bad impacts to the work or the job.

The gap of this study is to investigate the impact of being part-time-worker students on their academic achievement conducted at IAIN Kediri. It is greatly impossible to make sure that everyone can have a successful result as work-study students, because every single person has their characteristic and factor to deal with the work study deal. Based on the study conducted by Mussie et al. that having a part-time job is the biggest factor affecting the academic achievement. Therefore, coming back to the research finding is the best way.

The fourth previous study is entitled "Part-Time Job and Students' Academic Achievement" conducted by Safrul Muluk in 2017. This study involved 30 English Department students at UIN Ar-Raniry with a qualitative approach. The length of work, the GPA as well as the job 
kinds are considered as the main parts of this research. The result of this study shows that even though they have a part-time job, the result of their GPAs are still above the average.

Some studies identified certain issues pushing the students to join part-time jobs, such as difficulties in coming to the university, problems in academic deal, and difficulties in group assignments, and tiredness which will lead to dropping out. All of those problems are fundamentally caused by the failed time management. Therefore, proper time management and having the right time proportion between studying and working are significant. The phenomenon of being part-time-worker students is greatly common at IAIN Kediri, therefore, this study used the part-time-worker students of the English department at IAIN Kediri. Going from that problem this study is conducted entitled the impact of being part-timeworker students towards their academic achievement".

\section{Methodology and Procedures}

This study is categorized as qualitative research in which the data are elaborated descriptively. The research determines qualitative research as the design of this study because the data which are derived can be explained deeply in detail. The explanation will be based on the facts which are derived. The data are correlated by the impact of time management on academic achievement for work-study students. Moreover, it is not easy to explore the data by using quantitative research so that design is avoided. The data which are obtained from the online questionnaire are elucidated systematically, methodologically, and rigorously. Qualitative research used in this research is a case - study. A case - study is a method intended to obtain deep information about investigating program, activity, event, group and individual. The data are proceeded by using some procedures and decided times (Creswell, 2013).

The population of this study is English department students at IAIN Kediri. That is because the phenomena of work-students are easily found. The questionnaire was distributed to get their response and they had an interview section with the researcher. The students who have part-time jobs and students who do not have part-time jobs were selected. The work-study students were used as the sample of this study. Fundamentally, the true responsibility of a student is to study, however, some students study while working at the same time. They are considered as the sample of this study. This study involved 44 respondents to fulfill the questionnaire and 10 informants to have an interview section.

The way researcher collects the data is by distributing the questionnaire and by conducting an interviewing. Both ways to collect the data are intentionally conducted because they have different strengths and weaknesses. Both the questionnaire and the interview were completed separately. However, the main data were derived from conducting the interview. The interview questions are adapted from the researched article "part-time job and students' academic achievement" by Safrul Muluk in 2017, researched article entitled "problematika dan solusi mahasiswa yang bekerja bagi keberlangsungan belajarnya" by Ircham Mashadi in 2015 and "student part-time employment: a case study at ton duct hang university in Vietnam" by C. Ngoc ha, N Trang Tao and T Dhin Son in 2016. The interview was 
conducted via google meet to minimize the face-to-face meeting because of COVID-19 restrictions.

The questionnaire was administered through google form. The questionnaire consisted of closed-ended questions. The responders have 5 options, such strongly agree, agree, neutral, disagree, and strongly disagree. The questionnaire was intentionally conducted to discover the surface information about the respondents. The questionnaire was adapted from "pengaruh kuliah sambil bekerja dan aktivitas belajar terhadap prestasi belajar mahasiswa angkatan 2011 jurusan pendidikan IPS UIN MALIKI Malang” by Khikmatul Hidayah in 2016 and researched article entitled "does part-time job affect college students' satisfaction and academic performance (GPA)? The case of a mid-sized public university" by Mussie T. Tessema, Kathrine J. Ready and Marzie Astani in 2014".

\section{Results and Discussion}

In this section the data are tabulated intentionally in a group to answer the research question, the data are presented in a table form for the questionnaire to support the data taken from the interview as the main data. The questionnaire and interview were intentionally-collected the data about the impact of being part-time-worker students on their academic achievement. The data are collected from 44 academic students for the questionnaire and 10 students for the interview section.

This chart provides a comparison between part-time-worker students who take education field and part-time-worker students who do not take education field.

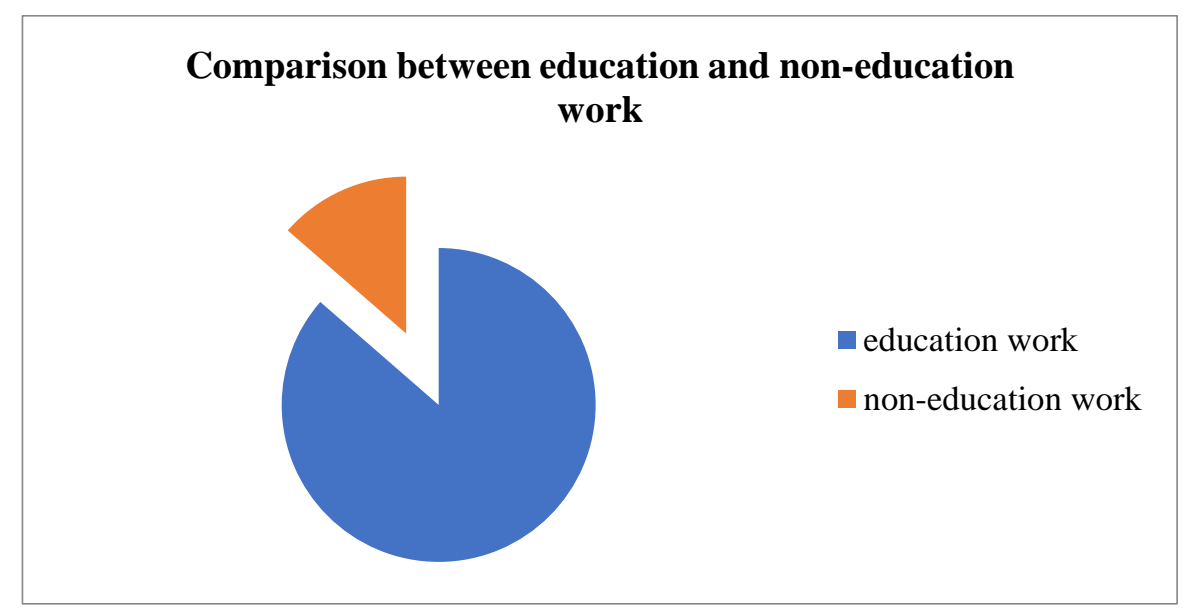

Figure 1: Comparison between Education and Non-Education Work

From the chart, we can conclude that most of the participants $86,4 \%$ prefer having a job which is tailored to their knowledge and study major, in this case, the English department. On the other hand, the rest of the data show that few students, $13.6 \%$ prefer having non-linear work with their educational background. Besides concerning the types of a part-time jobs, the motivation of students in preferring to be part-time-worker students or preferring to have those part-time-job types is considered as well to elaborate the reason why they decide to be a part-time-worker student. 
Based on the results of the study, there are two main reasons driving the students to be parttime-workers. First, many students ascribed this to the financial factor and also to experience factor. The first factor is similar to what Sari delivered with GPA of 3.6 and she took 4 hours to work as a tutor and an online seller:

"First of all, I learned how to teach. At first, I studied. I wanted to learn, like how to deal with children, so I can learn about the material too"

The second factor making the student engaged in part-time work is having financial issues. Students resort to taking a part-time job to provide sustenance for themselves. This is reflected in Nur's case who got GPA of 3.54 and took 9 hours to work as a tutor:

"The motivation because they need money, to pay for college we need money and you need money for the necessities of life"

From the answer, it can be concluded that the biggest motivation of being a part-time-worker student is the experience and the income or it is separated into two big fractions. The students indicated that they need more money or income to fulfil the maintenance. Other students stated that they join part-time jobs in order to acquire experience and develop their knowledge. It is also strengthened by the result of the questionnaire about having a part-time job which deals with motivation. Even though the strong motivation or not to be a part-timeworker is still possible to have.

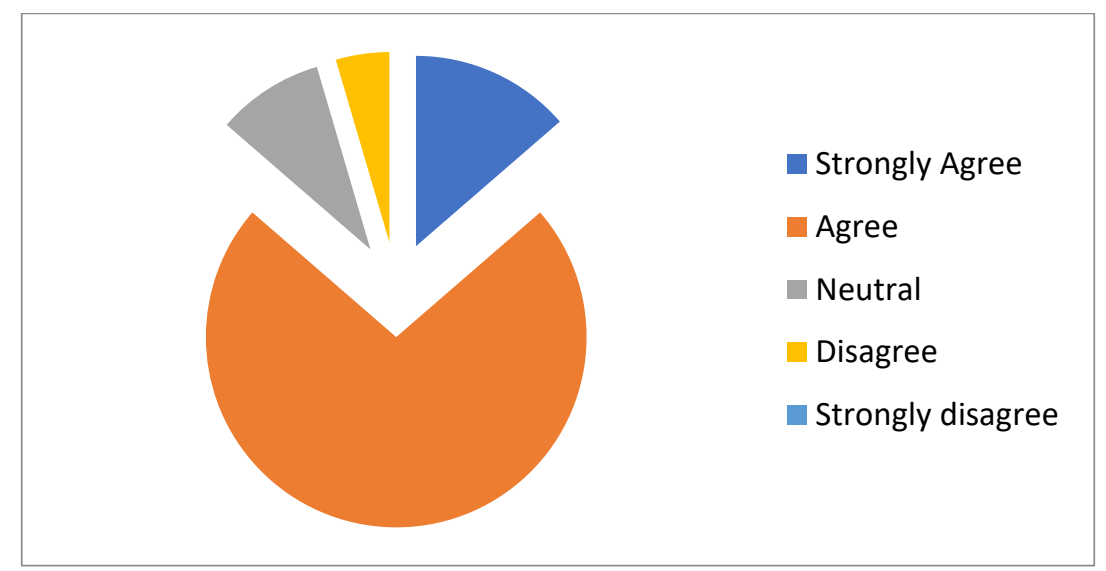

Figure 2: Questionnaire result about the possibility in being a part-time-worker student

Thirty-two students stated that being a part-time-worker student is still possible to have. Furthermore, 6 students stated that they strongly agree that it is still possible to be a parttime-worker student. Four students prefer to have a neutral answer. On the other hand, 2 students said that they disagree with the statement. A conclusion can be drawn that most students agree about being a part-time-worker student. It also has a meaning that even though their motivation is greatly strong but they are still able to prioritize the learning process. It is based on the result of the questionnaire. 


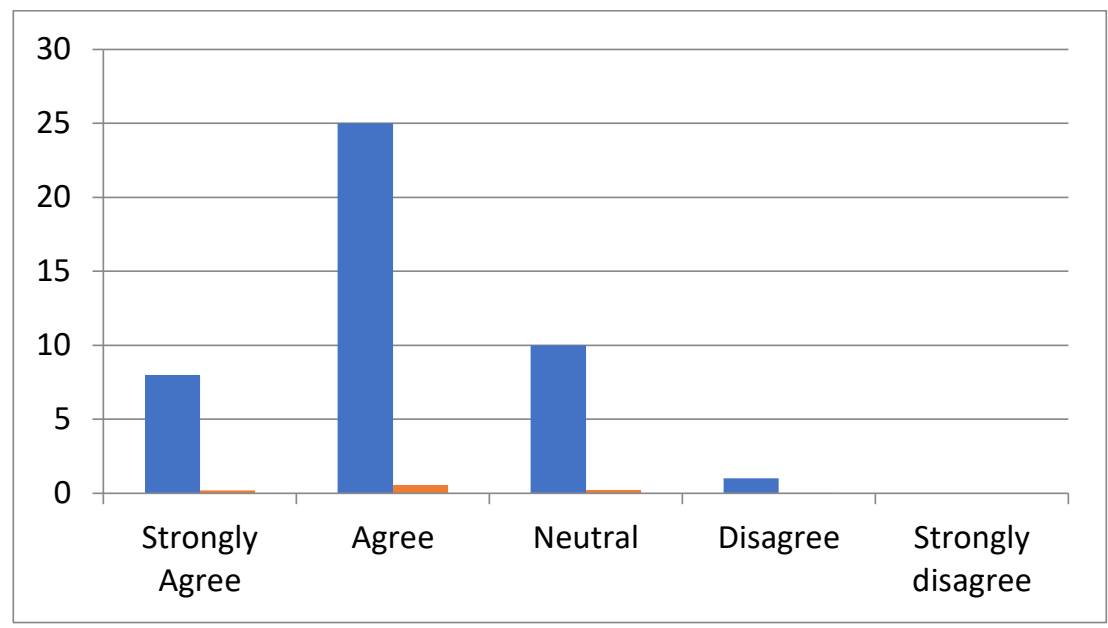

Figure 3: Questionnaire result about the ability to prioritize learning process

Twenty-five students agree that part-time-worker student is still able to prioritize the learning process. Furthermore, 8 students stated that they strongly agree that part-time-worker students can have priority in the learning process. Ten students prefer to have a neutral answer. On the other hand, 1 student said that they disagree with the statement. A conclusion can be drawn that most students agree about prioritizing the learning process.

The ability of the part-time-worker students is in line with the motivation why they have to be a part-time-worker student if they have reasons to earn money or seeking for experience, why they do not prefer to reach that by having other ways. However, there is not any other way to come to the purposes or aims that they possess in being a part-time-worker student. In other words, it can be achieved by being a part-time-worker student only. It can be strengthened by the statement delivered by Agung who is a part-time-worker student as a tutor in Pare, he gets GPA with 5-hour work duration:

"I don't want to talk about anyone's ugliness, yes, I study English language education, and I feel that there are no supporting facilities to improve or develop in English, so there is no place for it. Why in Pare because a lot of people are learning English and there are talking, answering in English, so I think it's okay to continue."

The answer to the question above shows that by being part-time-worker student, they can improve their ability or skill. It is also able to enhance knowledge and experience. Moreover, It becomes the only way to earn more income as well. It is also supported by the finding of the questionnaire which is in line that they are still able to catch the material very well. 


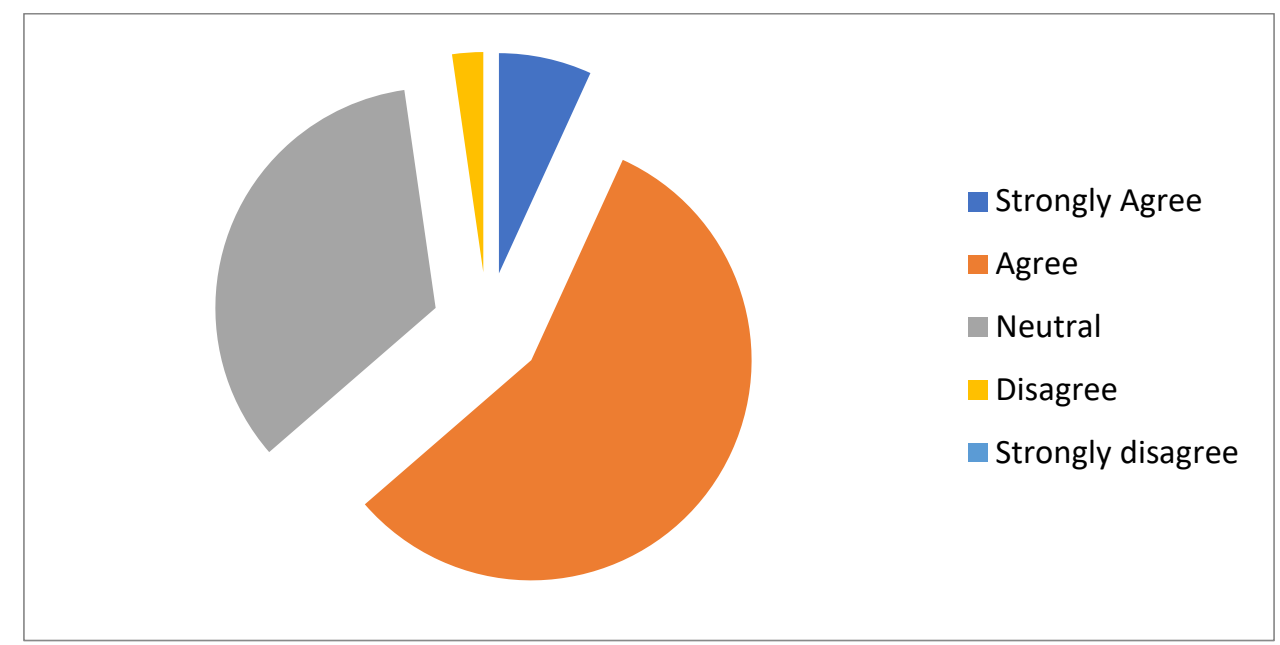

Figure 4: Questionnaire result about understanding the material in college

Three students strongly agree that they can do more than what they did about the material. Furthermore, 25 students stated that they agree that they fundamentally must do than before. Fifteen students prefer to have a neutral answer. On the other hand, 1 student said that they disagree with the statement. A conclusion can be drawn that most students agree in recognizing that they could have given the best. Moreover, the finding of the following questionnaire shows that the comprehension of the learning material is still well conducted.

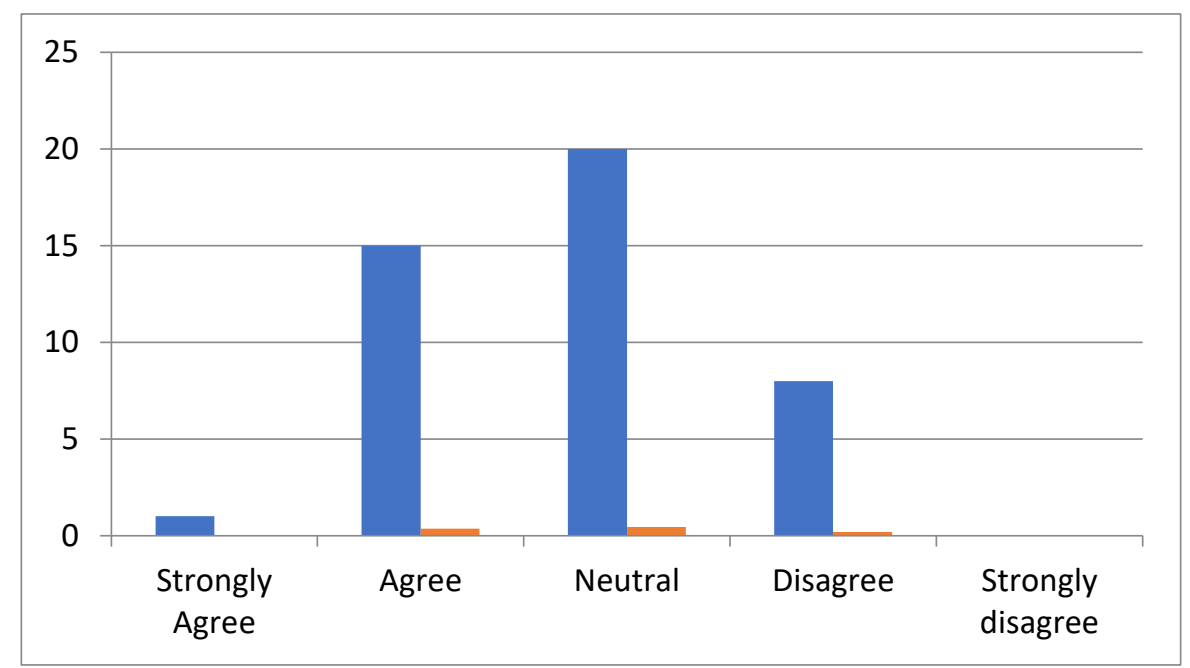

Figure 5: Questionnaire result about comprehension of material in college

One student strongly agrees that they can master the material well. Furthermore, 15 students stated that they agree that they can understand the material well. Twenty students prefer to have a neutral answer. On the other hand, 8 students said that they disagree with the statement. A conclusion can be drawn that most students have a neutral answer about mastering the material is still well conducted. The success of part-time-worker students in achieving academic achievement by having good comprehension is caused by good time management. It can be stated by taking a look at the statement from Gita Ajeng as a tutor with 7-hour work duration and she gets GPA of 3.43. 
"Because the majority of lectures are in the morning, so I have to focus according to the field at work and during college. So for assignments, I can do my homework at night or when I have a day off."

The answer above reflects that the student tries to manage the time by having a hope that they can make the time between working and studying balance. They try to minimize the time for having vacation, so that they victimize their weekend as well. It is also strengthened by the result of the questionnaire in asking the participants about time management.

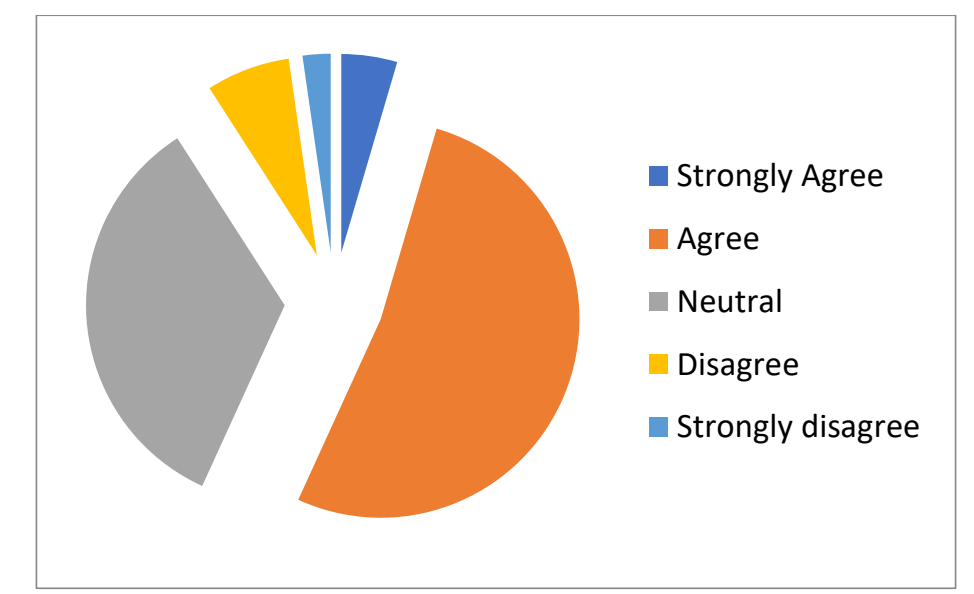

Figure 6: questionnaire result about possibility to manage the time

Two students stated that they strongly agree with the statement that the time between working and studying is still well managed even the students become part-time-worker students. Furthermore, 23 students stated that they agree that the time between working and studying is still well managed even they are part-time-worker students. Fifteen students prefer to have a neutral answer. On the other hand, 3 students said that they disagree with the statement. A conclusion can be drawn that most students are still able to manage time between time for working and time for studying. Moreover, it is also strengthened by the result of the questionnaire that the time of being a part-time-worker student is greatly flexible.

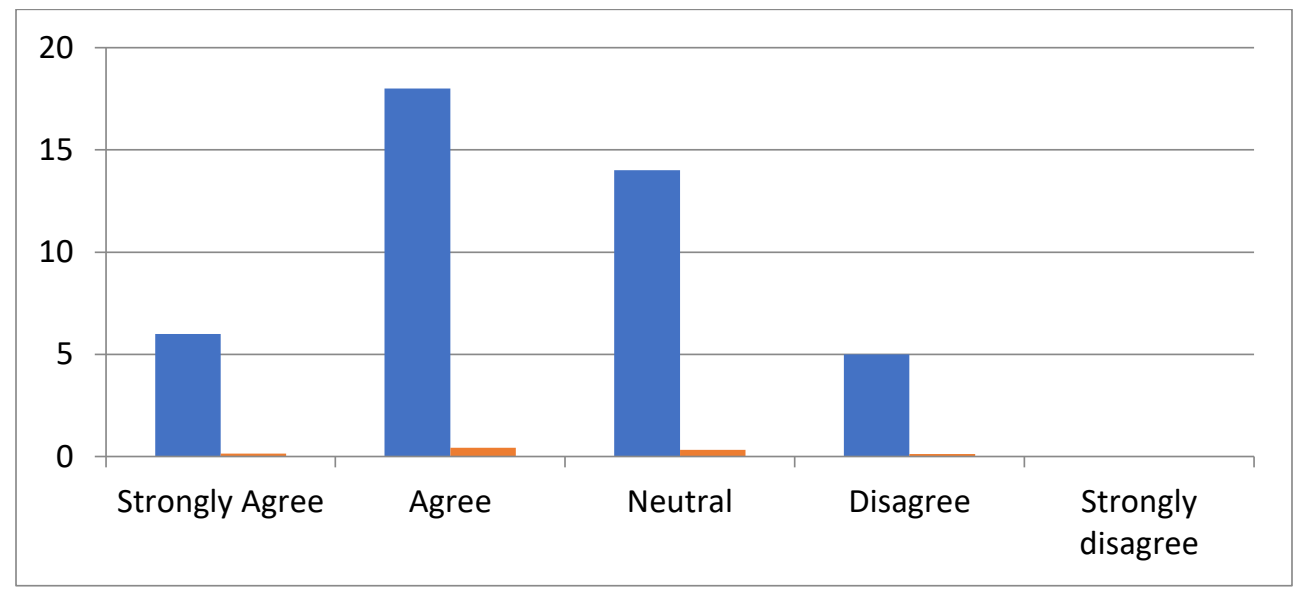

Figure 7: Questionnaire result about the flexibility of time

Six students stated that they strongly agree with the statement about the time at work which is flexible. Furthermore, 18 students stated that they agree that it is easy to make the time 
balance between working and studying because the time is flexible. Fourteen students prefer to have a neutral answer. On the other hand, 5 students said that they disagree with the statement. A conclusion can be drawn that most students have flexible time for working. The time means that it has a great correlation with duration or length for them to work. The manageable time between working and studying is the key for determining the success of being a part-time-worker student. From what informants state can be concluded that they mostly take less than 10-hour job duration. It can be referred to what Linda says as an employee in copy service with 6-7 hours and she gets GPA of 3.43.

A conclusion can be drawn that the length for being a part-time-worker student needed is around 7 hours. They try to find out the most flexible and short time because they also have learning activities. However, they have to make sure that they are still able to fulfil their maintenance. It is strengthened by the finding of the questionnaire as well about the duration of working.

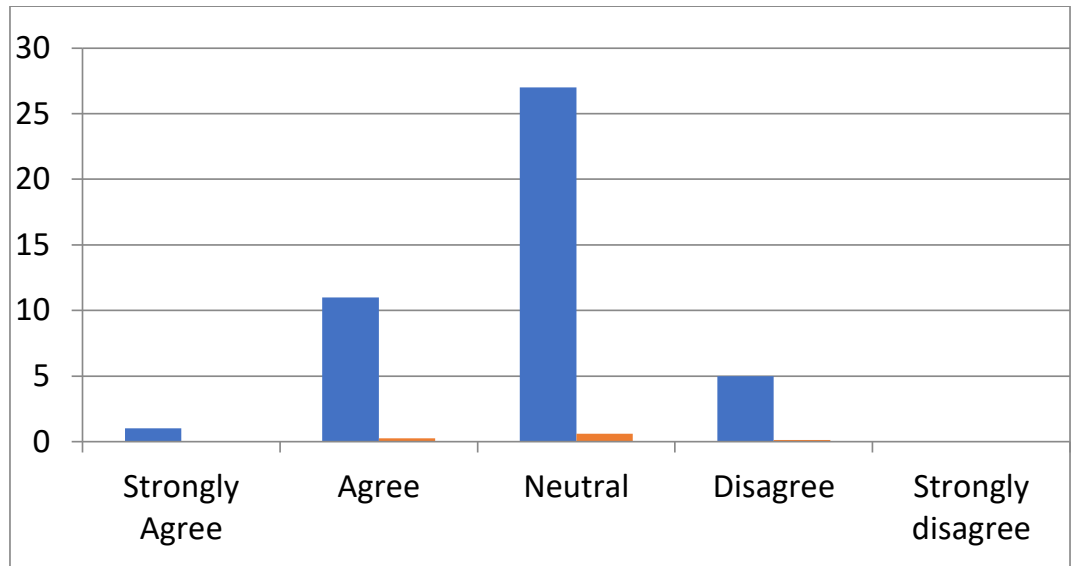

Figure 8: Questionnaire result that the duration of work is still fine

One student strongly agrees that they can have much time to brush up on the material. Furthermore, 11 students stated that they agree that they fundamentally still have enough time to reread or brush up. Twenty-seven students prefer to have a neutral answer. On the other hand, 5 students said that they disagree with the statement. A conclusion can be drawn that most students are still possible to brush up by considering their free time as well. Dealing with the part-time-worker students in working the assignment is greatly correlated with the work duration. The less work duration, the more study duration which it will to a better result in working on the assignment. It can be drawn from the statement of Feri who works as an employee with 8-hour work duration and he gets GPA of 3.51:

"It's undeniable that studying while working is not easy, so we have to be smart in dividing our time, sometimes we list first which is more important or prioritize like that, so right now my focus is at this stage, I'm also taking part-time work so if college, so college is prioritized first."

A conclusion can be drawn that the students try to do their best to manage the time effectively. They also try to consider and prioritize everything handled by themselves. They 
also try to list and arrange the schedule to facilitate. Moreover, the questionnaire about working on the assignment by the part-time-worker student.

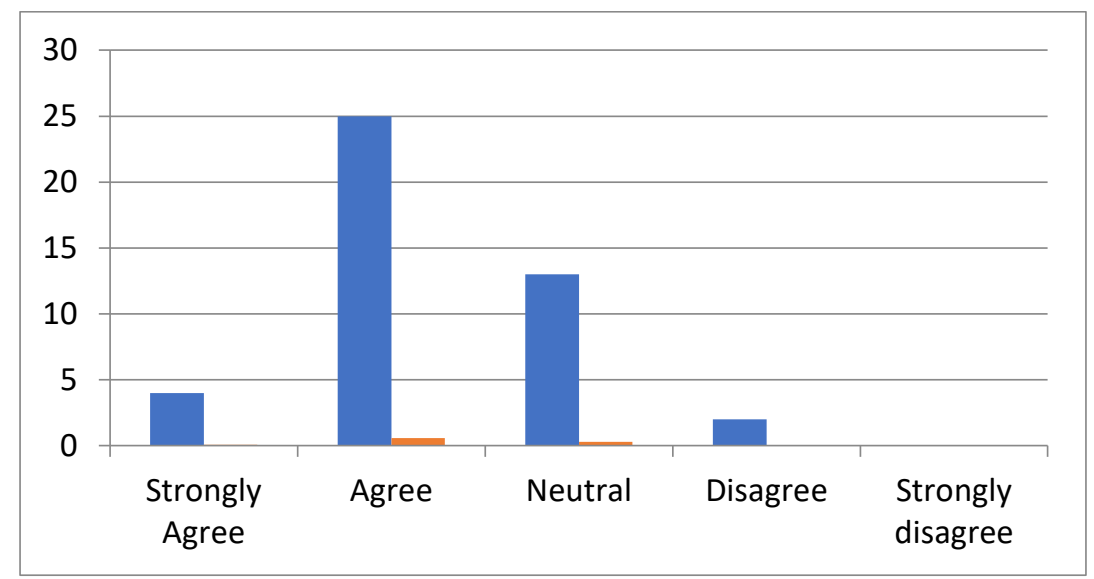

Figure 9: Questionnaire result about working on the assignment

Four students stated that they strongly agree with the statement that working on the assignments even the students become part-time-worker students is possible to own. Furthermore, 25 students stated that they agree that the assignment is still well done even they are part-time-worker students. Twenty students prefer to have a neutral answer. On the other hand, 7 students said that they disagree with the statement. A conclusion can be drawn that most students have neutral answer in making the time for working and studying balance. Successful time and assignment management leads to further improvement. The assignment from the place where they study and work must give tasks which must be done by the parttime-worker students. If they can pass on it, it means that they get a new experience and knowledge. It can be started from the statement of Qumil Laila who works as a tutor and school staff with 7-hour work duration and she gets GPA of 3.37:

"In my opinion, if I am in the field of education then I can hone my skills in the field of education, for others, yes, they can definitely hone their skills because the jobs they take are definitely what they are good at"

The same thing goes to the statement from Sari who works as a tutor and an online seller with 6-hour work duration and she gets GPA of 3.6: "Yes, if we can train our skills in socializing with people, then we will get the skills to work with people, how about our professionalism"

It can be concluded how to get more advantages by being the part-time-worker student. They try to utilize this chance to seek what they want, gaining more experiences and knowledge. Being part-time-worker is their own decision or demand, however, they are still able to utilize it to improve their skills and ability. Perhaps, those skills and abilities can be got only by being a part-time-worker student. Moreover, by having linear part-time job which improves the part-time worker's ability in both of work and study. In other words, the part-time worker can maximize the material and experience that they get in place where they work and study. It is in line with the statement of Sari who works as a tutor and an online seller with 6-hour work duration and she gets a GPA of 3.6: 
"So I studied it when I was in college, so I learned it when I was on campus, so when I was on campus I didn't play around, so I focused on campus, so when I work I don't think about college assignments, so when I get home from work I just do my homework and then read as much as I can."

The same statement goes from Nur who works as a tutor with 9-hour work duration and GPA of 3.54:

"I personally usually like browsing, so if there is a material that I don't understand, I can search it on Google, and if I don't understand on Google, I will open YouTube if asked about strengthening the material"

From the answer above, the students want to focus on the material that they get in college maximally, because it is their priority. There are two ways from such focusing on one attention, for example, they have totally to focus when they are at either workplace or college. The next way is by utilizing internet access to strengthen their comprehension related to a certain topic. It is in line with the result of the questionnaire.

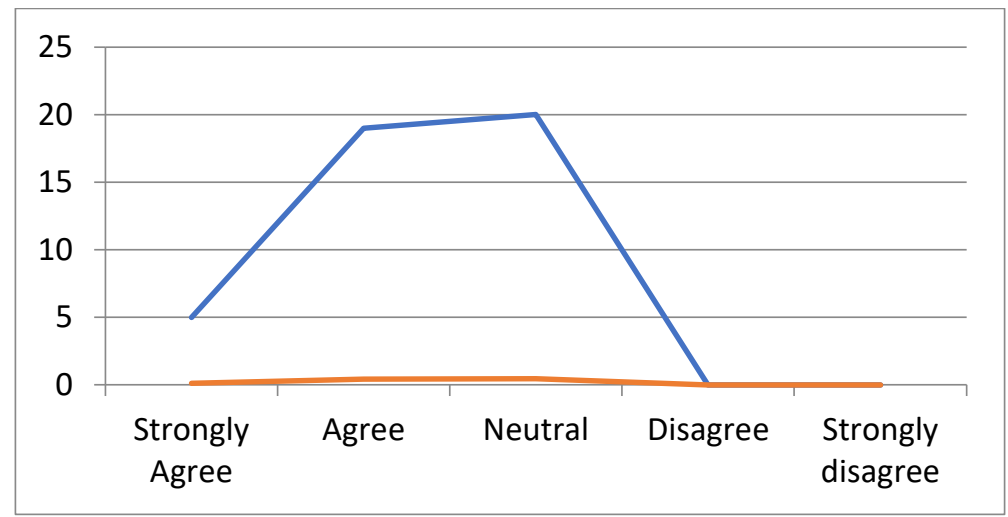

Figure 10: Questionnaire result about having autonomous learning to catch up the material

Five students strongly agree that they give efforts to reach the expected GPA. Furthermore, 19 students stated that they agree that they give efforts to reach the expected GPA. Twenty students prefer to have a neutral answer. A conclusion can be drawn that most students have a neutral answer about giving efforts to reach the expected GPA. The result of the questionnaire is in line with the result of the interview as well. It is stated by Annisa who works as a tutor with 3.5-hour work duration and she gets GPA of 3.45

"So far I am Alhamdulillah, I can understand the material, so we try to maximize everything, now there is the internet so we can open the internet and we can also ask friends, and we can discuss"

The same statement is given by Agung who is a part-time-worker student as a tutor in Pare, he gets GPA of 3.45 with 5-hour work duration :"I asked my friend who is smart too, yes, even though everyone is smart, it's relative, so I asked my friend who can if my friend can't browse" 
It can be concluded that they also want to catch up on the missed material. Various ways they have shown that they have a high desire to achieve a better result in academic performance. They try to utilize internet access as the easiest way they have to get maximal results or comprehension. They also have such discussions with their friends if there is confusion related to the material. The same case goes to discussion about the way they work on their assignments when they are busy. It is in line with the previous statement as well that both of the data show that the part-time-worker students stay doing some ways to achieve good academic performance. It is in line with the statement from Nur who works as a tutor with 9hour work duration and GPA of 3.54:

"So, in the past, I took a job and my lecture hours and work crashed, so I asked the lecturer for understanding to take his class in another class which automatically has different hours"

A similar statement is given by Qumil Laila who works as a tutor and school staff with 7hour work duration and she gets GPA of 3.37: "I will lobby my job first because it involves activities, individual assignments on campus, so I lobby for work first, when I finish my college assignments, I will continue my work".

From the answer above, the student has various ways to face the same thing, for example when they have crashed time between working and studying, they can try to move the time for studying to work, on the other hand, it is also possible to make a deal with the place where they work at. So, both of those answers represent that they want to make the work and study balance. However, in the running of the process, there is some demand for the parttime-worker students. The demand comes from both the place where they work and the place where they study. It is based on what Qumil Laila said. She is a part-time-worker student who works as a tutor and school staff with 7-hour work duration and she gets GPA of 3.37:

"Parents want their children to have progress, the first one is, then the second one must be on-time, what at school the demand is that we have to give a lot of time at the place if there are activities meetings, that's the demands."

It is in line with the statement from Linda who works as an employee in copy service for 6-7 hours and she gets GPA of 3.43:

"For teaching, if we teach there, we are required to focus on what students don't understand, from there we can learn what is not known to be known, in stores how to socialize with customers, how to serve them is the main thing for their satisfaction."

From the answer above, it can be concluded that even they are part-time-worker students, they still get the demand from the place where they work at. However, they try to utilize it as a skill improvement for themselves. The demand is minimalized and managed well to avoid 
the problem in the next few days. If all of the obstacles can be well handled, the good academic result will be easily got. It is in line with the statement from Rida who works as a tutor with 5-hour work duration and she gets a GPA of 3.54: "Alhamdulillah, if it's GPA, even though I can still get the maximum GPA work, because of that, I still have to prioritize college."

The same case goes for Nur who works as a tutor with 9-hour work duration and GPA of 3.54 .

"The GPA I got was compared to before I took the part-time job, so I used to be standard, so after I took my part-time job there was an increase in learning that required me to understand the material I was teaching, so there was an improvement." in my GPA, so this part-time job is very useful for me."

From, the answer above they try to give their best to achieve a better result in their academic performance. Moreover, the second informant said that being a part-time-worker student can increase their grade point average. It has a strong correlation between academic achievement and being a part-time-worker student. The obstacles must be discovered during their efforts to achieve a good academic result. However, it must well be handled and taken over. It is based on the statement from Qumil Laila who works as a tutor and school staff with 7-hour work duration and she gets GPA of 3.37

"If you minimize the challenge, you need to manage the time, right, if there is a conflict between college and work, for example, if the task has a long deadline then I will work again, and then when the deadline is over, I focus on the task first, so I manage the time more."

The same statement is also stated by Annisa who works as a tutor with 3.5-hour work duration and she gets GPA of 3.45: "If you minimize it, that is, if there is a task, don't delay it postpone it, in installments, continue to divide your time as best you can, the third priority is"

On the other hand, Sari who works as a tutor and an online seller with 6-hour work duration and GPA of 3.6 stated: "The obstacle is that if you can maintain your health, God willing, the obstacles can be overcome". From this answer, a conclusion can be drawn that the obstacles they face can be minimized by managing the time among dealing with the assignment, working, and studying as effectively as possible. It is because the only way to make it balance, or in other words, it can be mentioned as the general and common obstacle. It is in line with the following statement from Qumil Laila who works as a tutor and school staff with 7-hour work duration and she gets GPA of 3.37

"Getting a higher GPA than now, right, this is the last semester because this is the only way to increase my GPA again, I can because I'm also sure I can go up because by looking at my internship score yesterday was also good." 
From the answer above, it can be concluded that they have the confidence to derive a better GPA for this semester. Being a part-time-worker student does not mean that they can't achieve progress in their academic performance. On the other hand, a question about students who are not part-time-worker students is also delivered. It is stated by Gita Ajeng as a tutor with 7-hour work duration and she gets GPA of 3.43.

From the answer above, they have an opinion according to their experience in being part-time-worker student, they think that student who does not have a part-time job must be able to utilize the time they have as good as possible on their academic achievement.

\section{Discussion}

The result of this study showed that higher academic students used as the samples stated that even they are part-time-worker students, they still get satisfying GPA every semester. Moreover, students indicated that they have higher GPA every semester after being the parttime-worker student. The questionnaire consists of 32 questions and is divided into 4 categories: Studying, working, ability, and grade point average (GPA). The first discussion is about studying, 38 students stated that part-time job for a student is still possible to have, it is because they are still able to prioritize the learning process. Moreover, they are still able to manage the time between time for working and time for studying balance and they are still able to work on the assignments punctually. Two students stated that it is better to avoid being a part-time-worker student because they cannot prioritize the learning process which is caused by the difficulty in managing the time, moreover they are not able to work on the assignments. On the other hand, 3 students stated that being a part-time-worker student is greatly complicated, it is in line with the statement that they cannot prioritize the learning process which is caused by the demand on working which leads to failed time management. Moreover, it is impossible for working on the assignments.

The second category is about working, there are 26 students reflected that the duties in working place are still well-conducted. Even though, they sometimes get so many demands from the place where they work so that sometimes they are busy with the work. However, most of the time the duties from work are not so heavy because the time is also flexible, moreover, they only have a short working duration, 6 hours in a day, it means that all of the possibility in working place like the demand and hectic time can be well handled. The main factor of the success in working the duties from the work is good time management, they arrange the duties and the time to avoid the crashed time which leads to failure in doing the duties from the working place. On the other hand, two students said that they get many problems with a place where they work because they cannot deal with the duties from the working place. It is caused by many demands from working place, long work duration, and moreover, they do not arrange the schedule to facilitate the deal with the time in doing the duties from the working place.

The third category is the ability. 33 students stated that they are still able to provide a special time to be able to strengthen their comprehension related to the material. They realize that they have to give more effort in being part-time-worker students to make between the work and the study balance. The balance between study and work leads to the satisfaction of obtaining a good GPA. That is because they are still able to study and reopen the material, it 
also can be done through working on the assignments seriously and rigorously to follow up the material. On the other hand, 2 students said that they sometimes skip the comprehension of the material. They fundamentally realize that they can do more than what they have done before about the material. Moreover, it can present a regret from the students about the academic deal. It is caused by the failed time management as well which leads to failed assignment works as well. It gives unsatisfied academic achievement to the students.

The fourth category is the grade point average (GPA), there are 41 students who said that they get a satisfying GPA. It is caused by the efforts they do as long as the time they become part-time-worker students. They also try to give expectations to achieve a high GPA by being part-time-worker students. It also shows that the previous points such as the studying activity, working activity, and ability are in balance or in line with the academic achievement. It can mainly be caused by good time management to make the work and the study balance. On the other hand, 1 student said that achieving a good GPA is impossible, which is caused by the imbalance among the previous factors, such as: studying activity, working activity and ability. It can be caused by the failed time management which leads to failure to work on the academic activity and achievement as well. Therefore, the student does not have the desire to expect a better GPA, and it also impacts the lack of effort made by the student.

To sum up, the students stated that it is significant to be a part-time-worker student for enhancing the experience which cannot be derived from college, moreover, if they have to be a part-time-worker student because of the financial motivation, being a part-time-worker student is the only way to succeed the academic process and also to fulfil the daily needs. The experience which is derived cannot be obtained in college only by being an ordinary student. However, being a part-time-worker student means that they have been ready to manage the time effectively between the time for working and the time for studying to make both balances. Part-time-worker student can arrange or list the schedules to facilitate them in conducting both studying and working. Being a part-time-worker student has two greatly different viewpoints if it is considered from the impact to the academic achievement, bad influence and good influence. The bad influence can be considered as the result of being a part-time-worker student if it makes the grade point average (GPA) lower. On the other hand, it can be mentioned as a positively influenced activity if by becoming a part-time-worker student can contribute the better result GPA. It is in line with the previous study that has two finding sides, positive and negative viewpoints (Gilabert et al., 2017). Dealing about being a part-time-worker student can become the main contribution to affect the academic achievement and the term of part-time-worker student can become something uncommon because the intensity is high, those are in line with the previous study (Mussie \& Tesema, 2014).

Moreover, students who have linear work with their major in college have advantages by utilizing the chance to learn more about the material which they did not pay attention to when they were in class of college. In this case, English department students who work in education field are stimulated to learn more about English. On the other hand, English department students who take non-linier work are still able to achieve stable GPA. 
It is definitely not simple to conduct but it goes well if the time is well paid attention. Being part-time-worker students fundamentally can give good influence to the students to improve the ability as well. The academic activity and achievement is still good. It is in line with the way they minimize the obstacles by keeping the body health, moreover the stress management must be well paid attention. The thing which must be emphasized by the parttime-worker student is the length of the work duration, in other words they have to obtain minimal duration for work but it can cover the purpose why they become part-time-worker student. Therefore, it can provide the time to focus on academic activity which leads to better academic achievement. In addition the same research finding is also elaborated in previous study conducted by (Kwadzo, 2014) and conducted by (Muluk, 2017).

They indicated that they have to take as minimal as possible for the work length. Moreover, they still have more significant activity, learning activity in college. However, they put a high expectation that the part-time job which has minimally duration of working can cover their aim or purpose. It is in line that the job duration or length gives high impacts to the academic achievement of part-time-worker student. Beside the time management, which has strong correlation on the impact of being part-time-worker students on their academic achievement. Being part-time-student cannot be separated with the existence of other substances as well. However, being part-time-worker student is not something impossible to have as a college student. It definitely must pay attention on the points such the next discussions presented.

Being part-time-worker student is strongly correlated with the academic learning activities because it becomes the main process had by the students in order come to a final in possessing a special honour as a part-time-worker student. However, even they have special difference with other ordinary students who focus on studying only, they fundamentally still prioritize their duty to be a student that is supposed to give a big belief to come to a good conclusion as students. The learning activities which have a goal to contribute the good result by the end of the learning process in college by the end of each semester. Learning activities mainly deal with the material to understand by the students and also deal with the academic work or assignment to finish. Both of the material and assignment have the same goal by the end by having an expectation that it can improve the academic knowledge of student represented by the grade point average (GPA). Each activity in learning process must be meaningful. It must be able to make sure to engage the development of students' skill and ability. The advanced development ability and skill of a student is supposed to be applied in real activity in life. It is also mentioned as meaningful activity as the goal or aim of a learning process. Moreover, the learning activity of part-time-worker student is totally different with the ordinary students. It is because it must deal with the time management of the learning process.

Beside academic learning activities, the learning time management also can be mentioned as one of significant parts in being part-time-worker students. Time management deals with the way someone manage the time as good as possible to work on activities demanding with the proper time arrangement. Moreover, the time management existing in being a student can be complicated because it is part of main activities which will take so long time in student's life in a day. There are two characteristics of students related with time 
management, the first character is students who have good time management which will lead to the better result in academic achievement, and the second characteristic is students who have poor time management which will lead to worse academic performance instead. Moreover, the time management of work-study-students is a main key or main factor contributing the big impact to the academic achievement as part-time-worker student. The well planned time management is supposed to make both of studying and working balance. Balancing the time between for working and for studying is challenging because it is something complicated and crucial to have as part-time-worker student. It is similar to the finding of another research having the same field (Kwadzo, 2014). Time management becomes the main determiner of the success in being a part-time-worker student.

The time for working on the assignments must be considered as good as possible because an assignment is the reflection of the main characteristics of the academic process which must be passed. The time estimation for dealing with the duties are considered as the main thing to have if a part-time-worker student wants to have better good academic performance. Working on the assignment is strongly correlated with the process academic activity. The assignment fundamentally can make the students expand their knowledge related to certain material. Moreover, by being part-time-worker student, the students must dedicate completely the time for working and studying. The part-time-worker student have lack time to have more pleasure as what ordinary students have. Part-time-worker students must have more effort to make the time between for working and for studying balance. It can be the biggest obstacle to have by part-time-worker student in conducting both studying and working at the same time.

Even they have to be part-time-worker students because of the financial factor as well as getting the more experiences by being part-time-worker student. However, they are still able to achieve good GPA and moreover they can achieve higher GPA every semester. On the other words, it can improve the ability of the student which leads to better academic achievement for those who utilize the chance in being part-time-worker student as good as possible.

\section{Conclusion and Suggestion}

The study aimed to investigate the impact of being part-time-worker students towards their academic achievement. The researchers used qualitative method to analyze data. Based on the findings of the study, it can be concluded that being part-worker-student does not affect students' academic achievement. However, some students have different perceptions. Being part-time-worker students sometimes is not a choice but it is a necessity. In some cases, being part-time-worker student is the only way to earn money and overcome financial crises. In addition, the findings of the study indicate that other students' motivation to join part-time jobs is to seek more experience. However, being part-time-worker student does not mean that they have to get bad academic achievement, instead, they are also still able to get good academic achievement or even better result every semester. The experience that they get in being part-time-worker student in real work situation is greatly valuable. It can be concluded that the part-time-worker student has more experiences than ordinary students who do not 
have part-time job. Though students seek the minimal duration for working, it is still able to cover the purposes, getting income and experience. More importantly, such student experience requires good time management which leads to better academic result.

\section{Conflict of Interest}

The authors declare no conflict of interest.

\section{Funding}

The study was not funded by any institution/ university.

\section{References}

Akuegwu, B. A., Ntukidem, E. P., Ntukidem, P. J., \& Jaja, G. (2011). Information and communications technology (ICT) facilities utilization for quality instructional service delivery among university lecturers in Nigeria. Review of Higher Education in Africa, 3(1),33-53

Ali, S. A. (2017). Analyzing undergraduate students' performance using educational data mining. Computers \& Education, 113, 177-194.

AL-Muslimawi, I. A. J., \& Al-Faroun, W. A. A. (2019). The Effective Method of Corrective Feedback in English Language Learning. Journals eduction for girls, 1(24), 5-20

Al, A. D., \& Anıl, İ. (2016). The comparison of the individual performance levels between full-time and part-time employees: the role of job satisfaction. Procedia-Social and Behavioral Sciences, 235, 382-391.

Barrow, L., Richburg-Hayes, L., Rouse, C. E., \& Brock, T. (2014). Paying for performance: The education impacts of a community college scholarship program for low-income adults. Journal of Labor Economics, 32(3), 563-599.

Beefy, R. (2010). The work-study relationship: experiences of full-time university students undertaking part-time employment. Journal of education and Work, 23(5), 439-449.

Cassidy, S. (2012). Exploring individual differences as determining factors in student academic achievement in higher education. Studies in Higher Education, 37(7), 793-810.

Daulay, E., \& Muhson, A. (2011). Mahasiswa bekerja dan dampaknya pada aktivitas belajar dan prestasi akademik. Jurnal Economia, 13(2), 201-209.

Dipboye, B. W. (2014). Moderating Effect of Organizational Factors on the Relationship between Diversity Management Strategy and the Performance of Public Universities in Kenya. European Journal of Business and Management, 6(24), 177-183.

Fetters, M. D., Curry, L. A., \& Creswell, J. W. (2013). Achieving integration in mixed methods designs - principles and practices. Health services research, 48(6pt2), 21342156. 
Gbadamosi, G., Evans, C., Richardson, M., \& Ridolfo, M. (2015). Employability and students' part-time work in the UK: does self-efficacy and career aspiration matter?. British Educational Research Journal, 41(6), 1086-1107.

Gerards, R., de Grip, A., \& Baudewijns, C. (2018). Do new ways of working increase work engagement?. Personnel Review.

Graham, C., Cagiltay, K., Lim, B. R., Craner, J., \& Duffy, T. M. (2011). Seven principles of effective teaching: A practical lens for evaluating online courses. The technology source, $30(5), 50$.

Harb, N and El-sharawi, A (2006) factors affecting student performance Muunish personal Archived paper No. 13621

Khanam, N., Sahu, T., Rao, E. V., Kar, S. K., \& Quazi, S. Z. (2017). A study on university student's time management and academic achievement. International Journal of Community Medicine and Public Health, 4(12), 4761-4765.

Kwadzo, M. (2014). International students' experience of studying and working at a Northeastern public university in the US. Journal of International Students, 4(3), 279291.

Lizzio, A., Wilson, K., \& Simons, R. (2012). University students' perceptions of the learning environment and academic outcomes: implications for theory and practice. Studies in Higher education, 27(1), 27-52.

Morisano, D., Hirsh, J. B., Peterson, J. B., Pihl, R. O., \& Shore, B. M. (2010).

Setting, elaborating, and reflecting on personal goals improves academic performance. Journal of applied psychology, 95(2), 255.

Muluk, S. (2017). Part-time job and students' academic achievement. Jurnal Ilmiah Peuradeun, 5(3), 361-372.

Oettinger, J. (2011). Work-study conflict or facilitation? Time use tradeoffs among employed students. Young people and work, 72, 121-141.

Oloube, A. W. A. (2015). Impact of job satisfaction on employees performance an application on faculty of science and humanity studies university of Salman Bin Abdul-Aziz-Al Aflaj. International Journal of Innovation and Research in Educational Sciences, 2(1), 26-32.

Robert, J. (2010). The relationship between personality, approach to learning and academic performance. Personality and individual differences, 36(8), 1907-1920.

Rokicka, M. (2017). The impact of the institutional setting and policies on the economic situation of youth in insecure labour market positions in EU-28 \& Ukraine (No. 15). EXCEPT Working Paper

Rukmoroto, G. (2012). Motivasi belajar pada mahasiswa ditinjau dari status bekerja (Doctoral dissertation, Prodi Psikologi Unika Soegijapranata). 
Rijavec, M., Ljubin Golub, T., Jurčec, L., \& Olčar, D. (2017). Working part-time during studies: The role of flow in students' well-being and academic achievement. Croatian Journal of Education: Hrvatski časopis za odgoj i obrazovanje, 19(Sp. Ed. 3), 157175.

Spady, W. G. (2011). Lament for the letterman: Effects of peer status and extracurricular activities on goals and achievement. American Journal of Sociology, 75(4, Part 2), 680-702.

Tessema, M. T., Ready, K. J., \& Astani, M. (2014). Does part-time job affect college students' satisfaction and academic performance (GPA)? The case of a mid-sized public university. International Journal of Business Administration, 5(2), 50.

Travail, C., McNeish, S., \& McColl, J. (2015). The impact of part time employment on students' health and academic performance: a Scottish perspective. Journal of further and higher education, 29(4), 307-319.

Undang-Undang Republik Indonesia Nomor 13 tahun 2003 Ketenagakerjaan. 25 Maret 2003. LN.2003/NO.39, TLN NO.4279, LL SETNEG :79 HLM

Woodley, M. A., Figueredo, A. J., Brown, S. D., \& Ross, K. C. (2013). Four successful tests of the cognitive differentiation-integration effort hypothesis. Intelligence, 41(6), 832842 . 